\title{
Turning the rumor of the May 11, 2011, earthquake prediction in Rome, Italy, into an information day on earthquake hazard
}

\author{
Concetta Nostro ${ }^{1,}$, Alessandro Amato ${ }^{1}$, Giovanna Cultrera ${ }^{1}$, Lucia Margheriti ${ }^{1}$, Giulio Selvaggi ${ }^{1}$, \\ Luca Arcoraci ${ }^{1}$, Emanuele Casarotti ${ }^{1}$, Raffaele Di Stefano ${ }^{1}$, Simona Cerrato ${ }^{2}$, and the May 11 Team $^{1, \dagger}$
}

\author{
${ }^{1}$ Istituto Nazionale di Geofisica e Vulcanologia, Rome, Italy \\ ${ }^{2}$ SissaMedialab, Trieste, Italy
}

\section{Article history}

Received January 11, 2012; accepted February 16, 2012.

Subject classification:

Seismic hazard, Education and outreach, Seismic risk reduction.

\begin{abstract}
A devastating earthquake was predicted to hit Rome on May 11, 2011. This prediction was never officially released, but it grew on the internet and was amplified by the media. It was erroneously ascribed to Raffaele Bendandi, an Italian self-taught natural scientist who studied planetary motions and related them to earthquakes. Indeed, around May 11, 2011, there was a planetary alignment, and this fed the credibility of the earthquake prediction. During the months preceding May 2011, the Istituto Nazionale di Geofisica e Vulcanologia (INGV) was overwhelmed with requests for information about this prediction, by the inhabitants of Rome and by tourists. Given the echo of this earthquake prediction, on May 11, 2011, the INGV decided to organize an Open Day at its headquarters in Rome, to inform the public about Italian seismicity and earthquake physics. The Open Day was preceded by a press conference two days before, to talk with journalists about this prediction, and to present the Open Day. During this 'Day', 13 new videos were also posted on our YouTube/INGVterremoti channel to explain earthquake processes and hazards, and to provide periodic updates on seismicity in Italy from the seismicity monitoring room. On May 11, 2011, the INGV headquarters was peacefully invaded by over 3,000 visitors, from 10:00 am to 9:00 pm: families, students with and without teachers, civil protection groups, and many journalists. This initiative that was built up in a few weeks has had very large feedback, and was a great opportunity to talk with journalists and people about earthquake prediction, and more in general about the seismic risk in Italy.
\end{abstract}

\section{Introduction}

The news that an earthquake would strike Rome on May 11, 2011, had been circulating for weeks on blogs and websites, and in newspapers and on television, and it had resulted in a collective psychosis. Starting from March 2011, the Istituto Nazionale di Geofisica e Vulcanologia (INGV) seismologists received requests for explanations and reassurance about this prediction, by the inhabitants of Rome and by tourists.
To answer such questions, we first made a short YouTube video, entitled Earthquake in Rome on May 11, 2011? This was designed to better explain the story of the presumed prediction, which had been attributed to Raffaele Bendandi. This video was uploaded on April 14, 2011, onto the YouTube/INGVterremoti channel, the official INGV YouTube channel that was started in February 2010 [see Amato et al. 2012, this volume]. As we were approaching the fateful date, the number of viewings of this video started to increase, along with the comments and questions. Then we included frequently asked questions on the INGV website, explaining briefly the Bendandi theory, the characteristics of the seismicity of Rome, the causes of earthquakes, and their nonpredictability.

Given the considerable social echo and media attention for this expected earthquake, the INGV decided to organize an Open Day on May 11, 2011, in its headquarters in Rome. This would be devoted to the public who wanted to learn more about Italian seismicity and earthquake physics. The Open Day was preceded by a press conference two days before, in which we talked about the prediction and presented the Open Day. We had scientific discussions with the journalists about earthquake prediction, and more in general on seismic hazard and risk in Italy. About 40 journalists from newspapers, local and national television, press agencies, and news websites attended the press conference, and hundreds of articles appeared in the following days, advertising the May 11 Open Day at INGV.

The INGV was open to the public all day long (10:00 am to 9:00 pm), and offered meetings with researchers, guided tours to the seismicity monitoring room, interactive exhibitions on earthquakes and the Earth's deep structures, and conferences on topics related to the Open Day.

Although many people remained with the fear (many decided to take a day off work and to leave town or stay 
out in the public parks) [De Luca 2011], we contributed to the reduction of this feeling, and therefore the social cost of this 'strange day' in the city of Rome. Moreover, we understood that these (fortunately sporadic) circumstances, when the attention of the people is high, are important opportunities for science communication.

Bendandi's theory was the origin of the rumors of this presumed prediction. Raffaele Bendandi was a craftsman and self-taught scientist, and he had never published
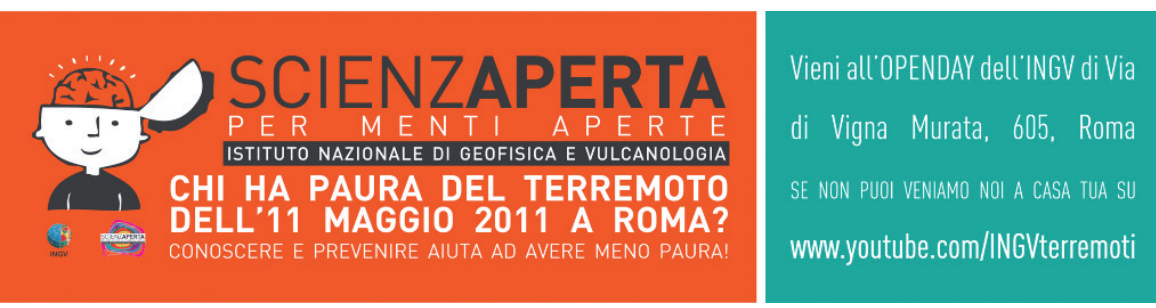

Figure 1. Invitations to the Open Day at INGV, showing the 'brand' of the event.

a verifiable scientific study of his theory. He became interested in planetary motions in the Solar System after a solar eclipse in 1905. Then, after the 1908 Messina earthquake, he began to study the tides, past earthquakes, and planetary alignments, setting up his own observatory with seismographs [Fidani 2008]. In 1920, he joined the Italian Seismology Society and began to develop his own theories, which he called 'seismogenics', relating to the nature of earthquakes. He believed that they were caused by alignments in the Solar System, and mainly by the Sun and the Moon. He argued that the forces generated as a result of these alignments can produce earthquakes [Lagorio and Dolcini 1992, Lagorio 2008]. It is worth noting that at that time, plate tectonic theory was not yet known.

Bendandi's theory has never been published in scientific journals, and has remained written in his notes and drawings, which are rather difficult to understand. The INGV is working with the Osservatorio Bendandi of Faenza to collect and catalog these writings. However, it should be noted that Bendandi's notes do not show any prediction of a possible earthquake in Rome for May 11, 2011.

\section{The communication plan}

It was on April 20, 2011, that we decided to organize the Open Day, just 20 days before the presumed earthquake (May 11). Therefore, we tried to organize a few essential and effective initiatives to solve this communication emergency.

We first defined the objectives and the tools available for the initiative. We created a 'brand' for our project, and asked the INGV Laboratory of Graphics and Images to design a logo. We chose to link the Open Day to a recent initiative of the INGV Laboratory of Scientific Education and Outreach, SCIENZAPERTA (OPEN SCIENCE)

(March-April 2011), and therefore the chosen 'brand' was: OPEN SCIENCE for OPEN-MINDED PEOPLE - Who's afraid of the May 11, 2011, earthquake in Rome? Knowledge and prevention help to reduce fear! (Figure 1).

We planned a press conference for May 9, 2011, two days before the date of the 'expected' earthquake, to provide direct information to journalists about the presumed prediction (Earthquake in Rome on May 11, 2011?, Alessandro Amato), and to inform the media about seismicity of the Italian territory, and about seismic hazard and ways to reduce it (Living with earthquakes: between education and awareness, Giulio Selvaggi). The final argument was for the Open Day and all the initiatives that we were bringing forward for the Open Day for the public (May 11, 2011: Open Day at INGV, Concetta Nostro). In the days before the press conference, we prepared a news release with the invitation to the conference and the announcement of the Open Day. On May 3, 2011, this information was sent by the INGV Press Office to about 1,200 journalists and to many web-

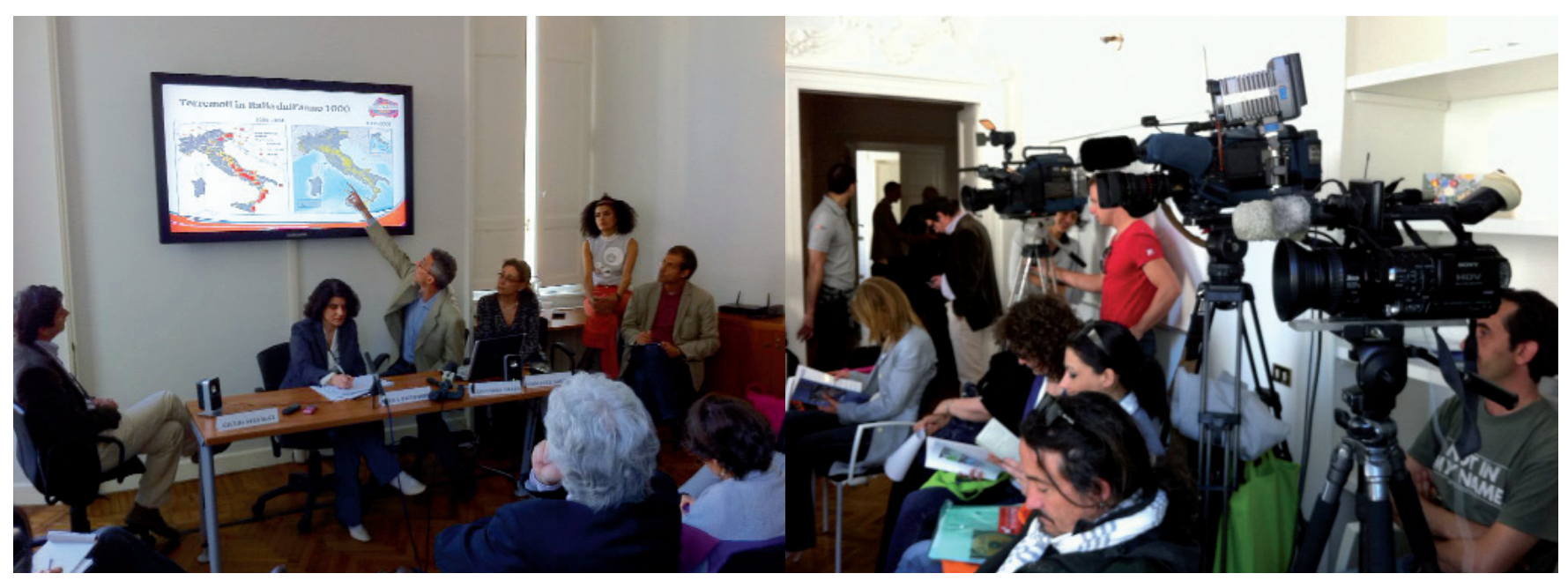

Figure 2. The press conference on May 9, 2011, held in the INGV office in the center of Rome, near the Quirinale. 
sites and blogs that had discussed the presumed prediction. With the guidance and collaboration of our Press Office, we prepared a folder containing maps, information and materials on the issues that would be addressed during the press conference: the seismicity and seismic hazard of Italy, along with some notes about the speakers.

The resonance that the prediction was having on people and on the internet attracted many journalists to our press conference. On May 9, 2011, more than 40 journalists from about 30 different agencies, newspapers, television and radio stations, and websites attended the press conference, including some qualified scientific journalists and international television. The conference lasted over an hour, and there was very active participation by the journalists (Figure 2). They were impatient to hear about the earthquake prediction and about related issues, and there was also effective moderation by Enrica Battifoglia, a very well known scientific journalist working for the Agenzia Nazionale Stampa Associata (ANSA), the main Italian press agency. They also had the opportunity to better understand the earthquake processes, seismic hazards and the possible strategies to reduce seismic risk. It was a rare opportunity of discussion and exchange ideas between scientists and journalists. At the end of the press conference, there were many individual interviews to give details to the journalists. Many appointments were set for May 11, 2011, at the INGV headquarters for real-time updates on earthquakes in Italy, and for information on the INGV Open Day.

We also informed scientific institutions and local authorities about our initiatives (press conference, Open Day and press releases), so that they could use them in answers to the public, for both those who live in Rome and for those who were in the Italian capital for business or pleasure. In the days preceding May 11, 2011, we received several requests for advice, and we knew that the municipality of Rome, and the provincial and regional administrations will have been literally overwhelmed with requests of all types.
We sent this information to the City of Rome, the individual municipalities, the Province of Rome and the Lazio Region, to help cope with the anxiety of the people and to invite everybody to the Open Day at INGV. We could not measure the impact of our initiative, but there is no doubt that our invitation and our press release were on more than 400 websites, including the official sites of the City of Rome and some of the municipalities, and the Province of Rome and the Lazio Region. Hopefully, this helped to further spread the information, to reduce anxiety, and to make life easier for administrators.

A critical element in our communication was that we were not categorically excluding a strong earthquake in central Italy, with relevant effects also in Rome, or a moderate event in the Alban Hills, the volcanic area close to the capital. Indeed, we know that Rome has low local seismicity, but as it is located on the edge of one of Italy's most seismic zones, the central Apennines, the seismic hazard in Rome is not negligible. In the past, some strong earthquakes of the central Apennines have caused damage in Rome (eg. in 1349, 1703 and 1915), even up to Mercalli grade VII, also because of the vulnerability of its old buildings [Rovida et al. 2011]. This circumstance, although very remote, could not be ruled out. Therefore, our initiative was devoted to inform people about seismicity and the seismic risk of Rome, and to explain the differences between short-term earthquake prediction (scientifically impossible) and probabilistic seismic hazard assessment (more scientifically sound).

\section{The Open Day}

The main goals of the Open Day were to answer requests from the public and to take advantage of its attention to establish a direct relationship between citizens and seismologists.

On May 11, 2011, the INGV opened its headquarters to the public. The program included:

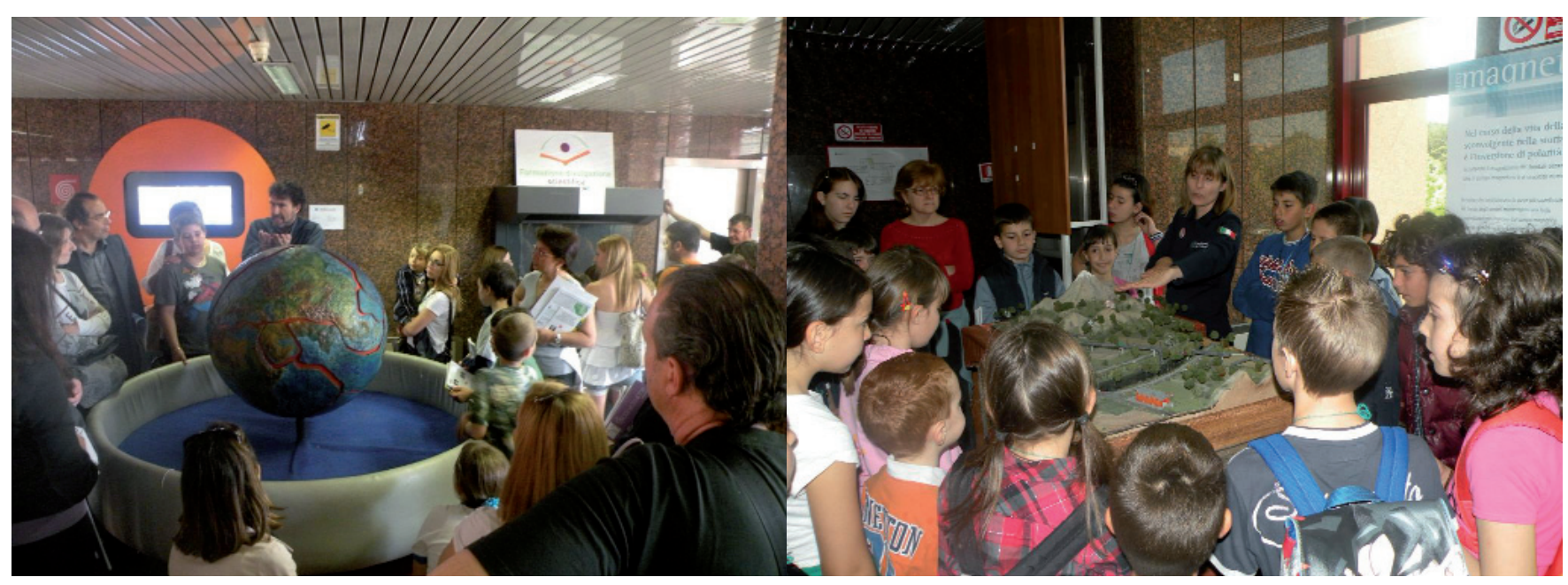

Figure 3. People visiting the earthquake and Earth interior exhibitions. 


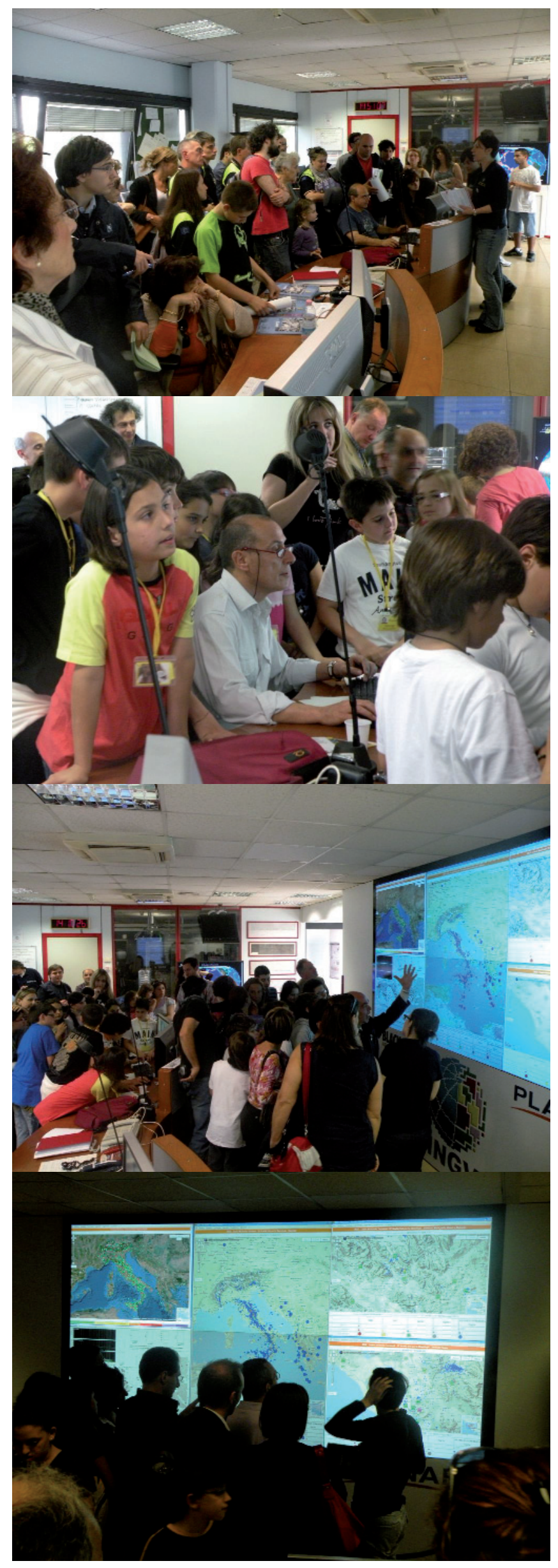

Figure 4. People inside the INGV seismicity monitoring room.
- meetings with seismologists, to answer questions on Italian seismicity and earthquake physics;

- guided tours of exhibits on earthquakes and the Earth's interior and magnetic field;

- guided tours in the 24-hour seismicity monitoring room;

- five afternoon lectures on the social impact of the rumors, and reduction of seismic risk.

All of these initiatives were linked into a single path that was proposed to the visiting groups that began to 'invade' the headquarters of INGV an hour before the official opening. The visit started with the showing of short videos (produced to be posted on the YouTube/INGVterremoti channel during the day) in the presence of a researcher, to give the public the opportunity to ask questions and to receive more detailed and accurate information.

The interactive exhibits about earthquakes allowed people to learn about the Earth's interior, and to understand where and why earthquakes occur in Italy and worldwide (Figure 3) [Nostro et al. 2005]. The interactive exhibits about geomagnetism allowed them to explore and understand how Earth's magnetic field is generated, and what its characteristics are [Winkler et al. 2005].

Then each visiting group was accompanied to the seismicity monitoring room, the place where the data arrive from the seismic stations distributed throughout the Italian territory. Here the staff, who are available 24 hours every day of the year, compute the hypocenter and magnitude of each earthquake that occurs in Italy (Figure 4), and send quick information to the Civil Protection Authorities. In this room, there were many of the seismologists who were normally engaged in the seismic monitoring shifts, who described the Italian seismicity in real time. The video wall in this room had been specially designed for this occasion, to show the distribution of the seismicity of the last 10 months throughout Italy and the city of Rome, to provide an instant overview of the situation.

At the end of the visit, each group was accompanied into another room, where it was possible to put specific questions to experts on seismic hazard in Italy and to see the distribution of historical and recent seismicity and seismic hazard in the different Italian regions [Pignone and Moschillo 2011]. During the tour, it was also possible to have information material, such as brochures, maps and books, provided by the INGV.

Moreover, visitors had the opportunity to participate to the Guess how many earthquakes there will be in Italy today game. This game was designed to make people aware that looking at the statistics, you can guess and predict the number of earthquakes that occur in a day (with some confidence intervals), although this is very different from making the prediction of one earthquake, indicating the exact location, date and magnitude. A student of a secondary 
school in Rome indicated the exact number (54), and won a T-shirt and some publications produced by the INGV.

In the afternoon of the Open Day, we organized five conferences on general topics: from the social impact of the spread of rumors, to the reduction of seismic risk. Researchers and technologists from different fields addressed the "question of the earthquake" from very different points of view. These included:

- Earthquakes in Rome, by Andrea Tertulliani;

- A un tale j'arisurta che a Roma, all'unnici de Maggio... (Someone knows that in Rome, on May 11...), by Massimo Crescimbene and Federica La Longa;

- The end of the world: a recurring theme, by Antonio Meloni;

- Prevent and predict earthquakes, by Angelo De Santis;

- Living with earthquakes, by Giulio Selvaggi.

These conferences were attended by many people (about 100-150 each), and they promoted great interest among the public.

\section{The YouTube/INGVterremoti channel and social networks}

Simultaneously with all of the information activities at the INGV headquarters in Rome, we designed a communication plan for people who could not come to the Institute, by posting a series of short videos on the YouTube/INGVterremoti channel [Amato et al. 2012]. There were three videos uploaded before May 11:
- Rome and earthquakes. This movie explains the characteristics of the seismicity of Rome, and describes the relationships between Rome and earthquakes.

- Earthquake in Rome on May 11, 2011? Through the contributions of INGV experts and the consultation of the original papers of Raffaele Bendandi, this movie tries to work out what was true in this presumed prediction of an earthquake in Rome for May 11, 2011.

- The program of the Open Day, added on our YouTube channel on May 9.

From May 11 at 00:30 to May 12 at about 01:30, 12 new videos were posted, partly made in the days before, and partly recorded live during the day, to explain how and why an earthquake occurs and to provide updates of ongoing seismicity in Italy from the INGV seismicity monitoring room.

These two types of movies on the YouTube/INGV terremoti channel had the dual purpose of providing general information on earthquakes, on the characteristics of historical and recent seismicity of the Italian territory, and on seismic hazard, while keeping the public updated on the progress of seismicity in real-time, to allow them to work out how many earthquakes occur in Italy in a 'normal' day.

The videos with updates from the INGV seismicity monitoring room also contained some brief, but essential, information about how the seismic surveillance service is carried out, and how the hypocenter and magnitude of an earthquake are computed.

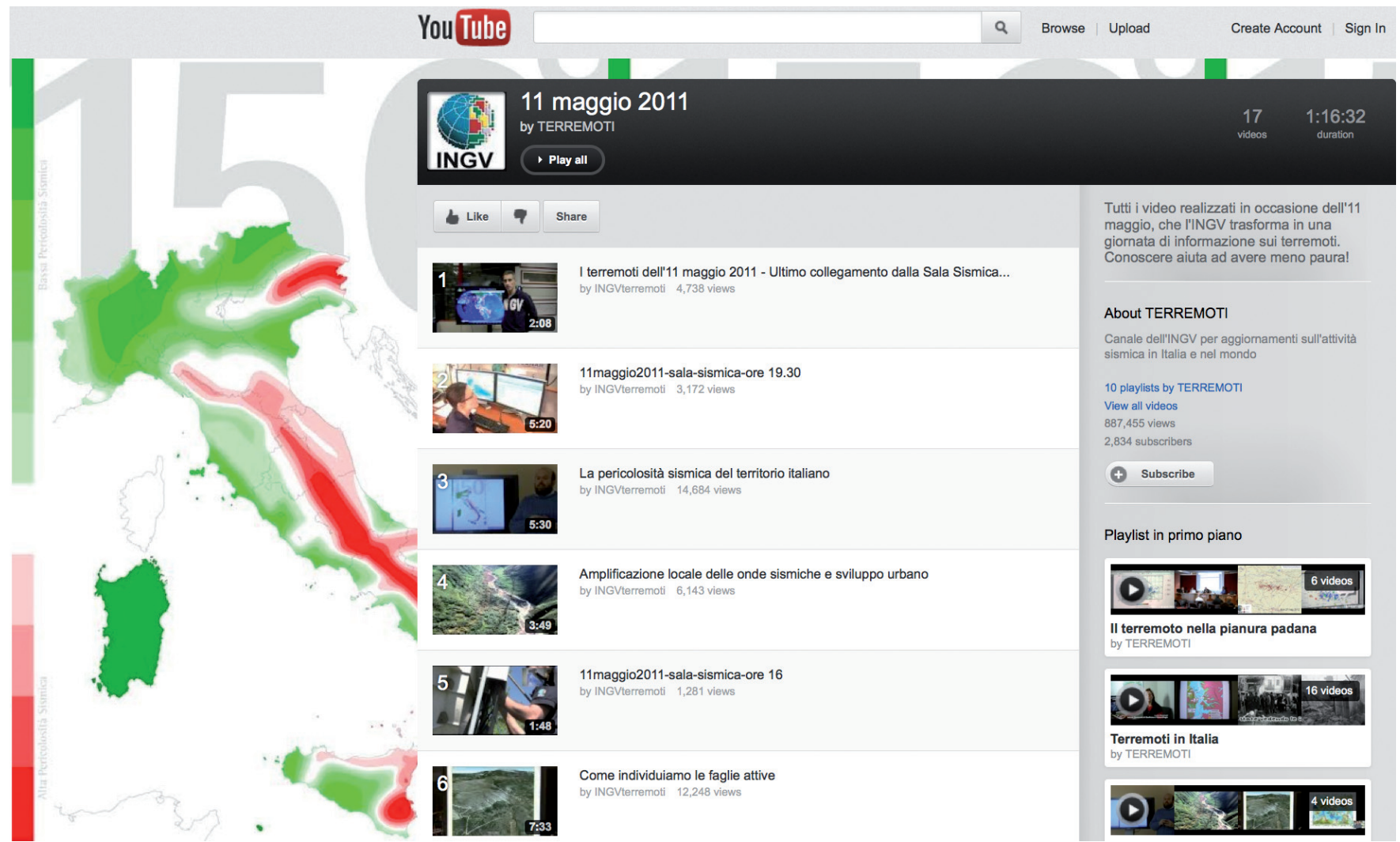

Figure 5. The 15 videos included in the 'playlist' named ' 11 maggio 2011 '. This playlist include all of the videos recorded for May $11,2011$. 
Considering all of the videos in the 'playlist' of May 11, 2011 (maggio 11, 2011; Figure 5), the total number of views was about 24,000 in one day (on May 11, 2011). To date, both 'Earthquake in Rome on May 11, 2011?' (over 67,000 views), and 'Rome and earthquakes' (more than 22,200 views) are among our most viewed videos.

Even on social networks, there was a lot of excitement in the days before May 11, 2011. From our experimental INGVterremoti Twitter site, we sent out a 'tweet' on May 10 stating that the INGV had organized an Open Day and a YouTube program on the INGVterremoti channel. The same information was also put on the Facebook page 'Terremoto Oggi', managed by INGV-Bologna.

\section{Impact on the media and the city}

Between May 7 and 14, 2011, the initiative promoted by the INGV was published in 130 newspaper and magazine articles, with over 450 articles on the internet, and 48 articles in the international press (Figure 6). Most of the articles were written after the May 9 press conference, to give voice to the information on the prediction and to announce the Open Day, although many other were written on May 12, to describe what happened at the INGV during the Open Day, and in the city on May 11, 2011.

From May 9 to May 14, 2011, we counted 48 television and 15 radio interviews. In particular, some local networks had updates during the day on what was going on at the INGV (specifying the number and kind of people participating, how many children, adults,

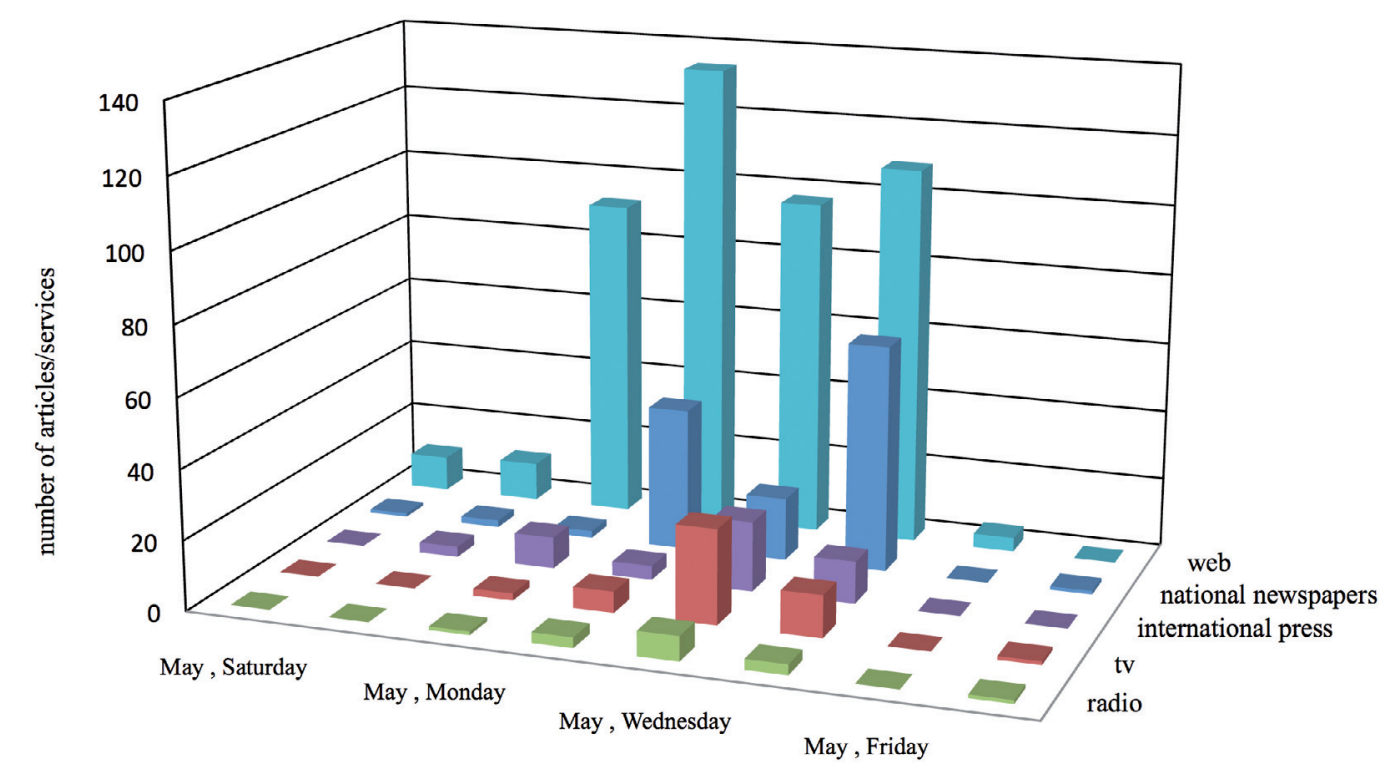

Figure 6. The number of articles on the web, in newspapers and in national magazines, and in the international press, and the number of interviews on television and radio services, from May 7 to May 14, 2011. Only the articles and interviews mentioning INGV are included. cation compared to the same day in 2010. Public employees were not the only ones who did not go to work, as many shops were closed that day. Moreover, the campsites along the coast near Rome were overwhelmed for the night and for the fateful day. It is interesting to note that the municipality of the city of Rome where the 'prediction' had more effect was Esquiline, where many businesses are run by people from China, a country that has a long tradition of attempts to predict earthquakes.

How did the institutions react? The Civil Protection Department of Italy developed and published on its website (www.protezionecivile.gov.it) on April 21, 2011, the dossier May 11: Earthquake in Rome?. This is a study devoted to the predictability of earthquakes and seismic risk in the city of Rome, which had over 20,000 users up to May 12, 2011. The City of Rome, the Lazio Region and the Province helped to disseminate information from the Department of Civil Protection and the INGV, and were invited to consider this fateful news in a rational manner. The news circulating on websites, blogs, newspapers, tel- and students), and about the seismicity in Italy and Rome.

The Open Day had a significant impact on the media and the public (Figure 7). Indeed, it is important to note that the INGV communication plan was addressed to the same media that contributed to the resonance of the story of the prediction. This allowed us to counter the unreasonable fear that they had produced. This activity was shown to be appropriate to avoid irrational and unjustified behavior, and to be effective with direct and immediate information.

How did the city of Rome react to the prediction? According to the daily newspaper "La Repubblica" on May $11,2011,20 \%$ more of the public employees were on va- 
site and the YouTube/INGVterremoti channel [see Amato et al. 2012, this volume], make us confident that our initiative was useful, and that it helped to limit the panic and reduce the social problems on May 11, 2011.

In this article, we have briefly summarized why and how we developed a communication strategy to face an emergency, such as the one triggered by a fake earthquake prediction in Rome on May 11, 2011. Although it was not a real emergency, the fear and uncertainty among the people required the time and attention of many seismologists, researchers, and technicians, to counteract the effects of this prediction. All of the INGV workers involved in the various stages of the May 11 Open Day felt a strong social responsibility: i.e., they contributed with their scientific knowledge to the calming down of people who were really afraid that a devastating earthquake would destroy Rome. Although we are aware that a strong earthquake in the central Apennines that even has relevant effects in Rome might occur, we tried to convince people that the level of risk on May 11, 2011, was the same as the days before and the days after; that earthquakes are natural phenomena, and that it is possible to cope with them, provided that prevention actions are taken.

Moreover, our initiative contributed to the improving of the relationships between scientists, the media, and society, and stimulated the broad and qualified participation of citizens in the scientific debate and in the basics of seismic hazard assessment. The opportunity was taken to share scientific and social knowledge on earthquake awareness and preparedness. As well as the so-called Bendandi prediction, we explained the real dimensions of seismic risk in Italy and worldwide, and what the role of seismological research is in risk mitigation.

Here we quote the words of the ANSA national press agency, as they summarized the INGV Open Day [ANSA 2011]:

"'People are afraid when they do not understand; it is like fear of the dark', said an old man as he left the INGV room where the researchers illustrated the seismic maps. Nearby, the 24-hour monitoring room was flooded by children with their mothers, grandmothers, and teachers. A class of high school 'Aristotele' had decided to come without their teachers. In every corner of the Institute, tens of researchers with maps and interactive models explained what earthquakes and faults are, and what seismic risk means, to more or less scared bystanders".

Knowledge reduces fear. Talking with people, explaining things with calm and confidence, is the way we have to face these emergencies, without hiding the real risks in a seismic country like Italy.

The measure of the success of this 'strange event' is not just the reduction of fear (hard to measure), but rather the awareness that we were ready and able to face a huge

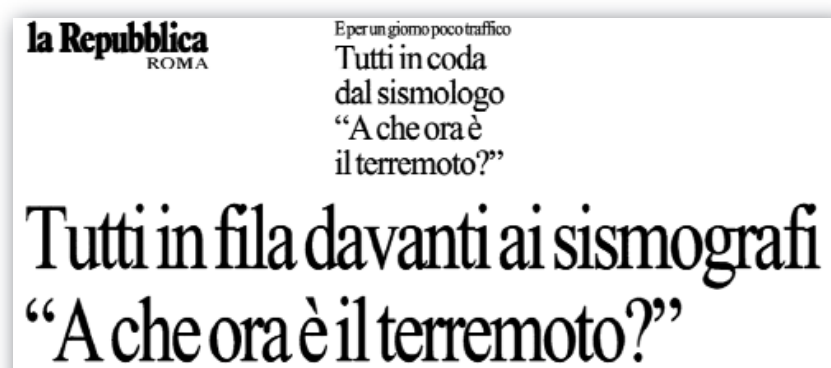

Etrairomanic'èchiprended'assaltol'istitutodiGeofisica

Figure 7. The headline of the daily national newspaper "La Repubblica" that appeared the day after the Open Day on May 11, to testify the extent and the effect of the initiative: "All lined up in front of the seismograph: 'What time is the earthquake?' And among the inhabitants of Rome, there are those who invade the Institute of Geophysics" [Erba 2011].

request for information and to restore the rightful role of correct scientific information. Our initiative countered the false information with a communication plan that had strong coordination and involved both the relevant sectors within the INGV and many experts of information and communication. To reach this result, we used conventional procedures, like the press conference and meetings with researchers, but also the social media, like YouTube, Twitter and Facebook.

We are strongly convinced that we can protect ourselves from the effects of earthquakes through awareness, prevention and education. A virtuous circle can be created among the worlds of science, communication and information, civil defense, and government, to reach the people and spread awareness of the risk.

Acknowledgements. We thank everyone who contributed to this initiative, and in particular: Enrica Battifoglia (ANSA) for her kind and effective moderation during the press conference; and INGV colleagues: P. Battelli, L. Postpischl, G. Rubbia and M. Stucchi, for the web interface; A. Meloni and G. Ferrari, for planning and participating in the video making about the presumed earthquake prediction; A. Serratore and M. Argenziano, for their precious help; and Paola Lagorio, President of the Osservatorio Bendandi of Faenza; the anonymous reviewer for the useful comments and suggestions.

\section{References}

Amato, A., L. Arcoraci, E. Casarotti, R. Di Stefano and the INGVterremoti team (2012). The INGVterremoti channel on YouTube, Annals of Geophysics, 55 (3); doi:10.4401/ag-5546.

ANSA (2011). Nessun terremoto a Roma, ma boom visite a INGV. Ricercatori in campo per informare e combattere le paure, Scienza\&Tecnica, May 11, 2011.

De Luca, M.N. (2011). Assenze boom negli uffici: la leggenda metropolitana Roma diventa psicosi, La Repubblica, May 10, 2011.

Erba, A.M. (2011). Tutti in fila davanti al sismografo: a che ora è il terremoto? E tra i Romani c'è chi prende d'assalto l'Istituto di Geofisica, La Repubblica, May 12, 2011. Fidani, C. (2008). Le previsioni di Raffaele Bendandi ispi- 
rate dal grande terremoto, 1908 - 2008 Scienza e società a cento anni dal grande terremoto, Reggio Calabria 10/12 December 2008, pp. 60-61.

Lagorio, P., and A. Dolcini (1992). L'uomo dei terremoti, Raffaele Bendandi, Faenza, Edit Faenza.

Lagorio, P. (2009). The epistolary archive of Raffaele Bendandi, a seismologist standing outside the institutions, Annals of Geophysics, 52 (6), 651-656.

Nostro, C., G. Cultrera, P. Burrato, A. Tertulliani, P. Macrì, A. Winkler, C. Castellano, P. Casale, F. Di Felice, F. Doumaz, A. Piscini, P. Scarlato, M. Vallocchia, A. Marsili, L. Badiali, A. Bono, S. Stramondo, L. Alfonsi, E. Baroux, M.G. Ciaccio and A. Frepoli (2005). Using earthquakes to uncover the Earth's inner secrets: interactive exhibits for geophysical education, Adv. Geosci., EGU, 3, 15-18.

Pignone, M., and R. Moschillo (2011). GEOSIS: dall'Earthquake Report al webGIS, Quaderni di Geofisica, INGV, n. 94.

Rovida, A., R. Camassi, P. Gasperini and M. Stucchi, eds. (2011). CPTI11, the 2011 version of the Parametric Catalogue of Italian Earthquakes, Milano/Bologna, http:/ / emidius.mi.ingv.it/CPTI.

Winkler, A., C. Nostro, P. De Santis, C. Castellano, L. Arcoraci, M. Berardi, A. Carosi, A. Meloni, E. Baroux, L. Alfonsi, A. Marsili, G. Cultrera, P. Ficeli, A. Bono, F. Di Felice, A. Piccio, D. Riposati, F. Di Laura, F. Di Stefano, S. Palone, A. Tertulliani, P. Macrì, A. Piersanti, A. De Santis, M. Vallocchia, A. Piscini, L. Badiali, F. Doumaz, P. Burrato, A. Frepoli, P. Scarlato and M.G. Ciaccio (2005). Interactive Exhibits for Geophysical Education: Uncovering the Secrets of the Earth, Transactions on Advances in Engineering Education, WSEAS, 2 (4), 375.

$\dagger$ The May 11 Team:

B. Angioni, M. Anzidei, A. Akinci, P. Baccheschi, A. Bannoni,

A. Basili, S. Bucci, P. Burrato, P. Casale, C. Castellano, T. Casula, M. Cerrone, C. Chiarabba, L. Chiaraluce, M. G. Ciaccio, A. Cianchi, F. Cinti, M. Crescimbene, L. Cucci, G. D’Addezio, N. D’Agostino, E. D’Anastasio, P. De Gori, G. De Luca, P. De Michelis, A. De Santis, D. Di Luigi, D. Di Mauro, A. Esposito, L. Faenza, C. Felli, G. Ferrari, R. Forsinetti, U. Fracassi, A. Frepoli, A. Galvani, R. Giannetto, L. Giovani, A. Govoni, I. Hunstad, F. La Longa, D. Latorre, V. Lauciani, V. Lombardo, P. Macrì, M.T. Mariucci, A. Marsili, S. Mazza, F. Mele, C. Meletti, D. Melini, A. Meloni, A. Michelini, M. Moretti, R. Moschillo, N. M. Pagliuca, M. Pastori, A. Piatanesi, A. Piersanti, D. Pietrangeli, M. Pignone, C. Piromallo, V. Pirro, M. Pisegna, L. Pizzino, E. Rocchetti, V. Sepe, A. Serratore, M. Silvestri, G. Soldati, D. Sorrentino, A. Tertulliani, S. Topazio, R. Tozzi, E. Trasatti, P. Vannoli, A. Venuti and A. Winkler.

${ }^{\star}$ Corresponding author: Concetta Nostro, Istituto Nazionale di Geofisica e Vulcanologia, Rome, Italy; email: concetta.nostro@ingv.it. 